УДК $81-11$

$10.17213 / 2075-2067-2020-3-141-146$

\title{
КОНЦЕПТ «БИЛИМ» (ЗНАНИЕ) \\ И ЕГО ЛИНГВОКОГНИТИВНОЕ ВЫРАЖЕНИЕ В ХУДОЖЕСТВЕННОМ ТЕКСТЕ
}

\section{(C) 2020 г. X. T. Абдурахманова}

\section{Ошский государственный университет, г. Ои, Киргизия}

В статье рассматриваются лингвокогнитивные вопросы кониеета «билим» (знание) в кыргызском языке на материале повести «Биринчи мугалим» («Первый учитель») Ч. Айтматова. Обосновываются актуальность и изель исследования, определяется необходимость лингвистического и культурологического анализа авторского видения мира через призму конщепта «билим» (знание). Изучается когнитивная структура концепта «билим» (знание) в иелом, а также анализируется его лингвокогнитивное использование в произведении «Биринчи мугалим» («Первый учитель»).

Ключевые слова: концепт; знание; кыргызский язык; художественный конщепт; языковая картина мира; индивидуально-авторская картина мира.

\section{THE CONCEPT OF «BILIM» (KNOWLEDGE) AND ITS LINGUISTIC AND COGNITIVE REFLECTION IN FICTION}

\section{(C) 2020 Kh. T. Abdurahmanova}

\section{Osh State University, Osh, Kyrgyz Republic}

The scholarly paper studies the cognitive concept of "bilim» (knowledge) in the Kyrgyz language based on the novel «Birinchi Mugalim» ("The First Teacher») by renowned Kyrgyz writer Ch. Aitmatov.The research outlines the relevance and aim ofthe paper; the necessity to study the author's philosophy on the concept of «bilim» (knowledge) is emphasized. The paper defines the cognitive structure of the concept «bilim» (knowledge); it also analyzes linguistic and cognitive nature of the concept of «bilim» (knowledge) in the novel «Birinchi Mugalim» ("The First Teacher») by Ch. Aitmatov.

Key words: concept; knowledge; Kyrgyz language; linguistic picture of the world; author's individual philosophy.

Данная статья посвящена лингвокогнитивному анализу концепта «билим» (знание) в художественном произведении «Биринчи мугалим» («Первый учитель») Ч. Айтматова. Целью данной научной статьи является исследование концепта «билим» (знание) и его лингвокогнитивное выражение в художественном тексте в кыргызском языке на материале повести «Биринчи мугалим» («Первый учитель») Ч. Айтматова. Актуальность исследования концепта «билим» (знание) в лингвокогнитивном аспекте, репрезентированного единицами кыргызского языка, характеризуется неизученностью в кыргызской национальной концептосфере. Данный концепт имеет важное место в сознании, познании, интеллек- 
туальном процессе и культуре кыргызского народа. Любое художестенное произведение создается индивидуальной интерпретацией автора. Однако автор выражает свою мысль через этнолингвистический контекст, который заложен в языковой картине мире народа. Как отмечает Е.В. Галдин, «языковая картина мира определяется когниолингвистическим статусом, тем, насколько адекватно в её отдельном речевом фрагменте, воспринимающемся субъективно, отражаются объективные моменты знания, исторического опыта культуры данного языкового этноса» [5].

Концепт как объект когнитивной лингвистики до сих пор не получил точную дефиницию. В настоящее время концепт изучается в разных направлениях в трудах Н. Д. Арутюновой, А. П. Бабушкина, А. Вежбицкой, Е.С. Кубряковой, С.Е. Никитиных, С.Г. Воркачева, В.Н. Телии, Р.М. Фрумкиной, О.А. Алимурадова и др. Проблемами когнитивной лингвистики в Кыргызстане занимаются 3.К. Дербишева, Дж. М. Тагаев, К. З. Зулпукаров, Е.И. Жоламанова, У. Камбаралиева, М. Атакулова и др.

Как отмечает Е.И. Жоламанова, «анализ научных работ, защищенных в Кыргызстане в последнее десятилетие, позволил выявить следующие направления в освоении новых лингвистических парадигм: этнолингвокультурология, межкультурная коммуникация. В этих диссертационных исследованиях уделялось внимание таким понятиям когнитивной лингвистики, как лингвокультурный концепт, языковое сознание, языковая личность, языковая картина мира» [7]. Как отмечает Р.Г. Погосян, «концепты играют важную роль в речевом поведении носителей языка, представляющих данную культуры. Концепт это семантическое образование, отмеченное лингвокультурной спецификой и тем или иным образом характеризующее носителей определенной этнокультуры. Это некий квант знания, отражающий содержание всей человеческой деятельности» [9]. Таким образом, в любом художественном произведении проявляется лингвокультурная и лингвокогнитивная специфика, которую выражает концепт.

Концепт «билим» (знание) представляет собой совокупность всех ментальных и познавательных процессов человека. В кыргызском языке концепт «билим» (знание) верба- лизуется лексемами: окуу (учение), мектеп (школа), илим (наука). Окуу - исконно тюрская лексема, которая встречается в Древнетюрском словаре как oqumak - чтение [6]. В современном кыргызском языке сочетания с этим словом выражают процесс получения знаний - башталгыч окуу (начальное образование), орто окуу жайы (среднее образовательное заведение), жогорку окуу жайы (высшее учебное заведение). Словосочетания с данной лексемой активно используются в книжной и нейтральной речи: окууга баруу (идти на учебу), окууга өтту (поступил учиться), окуудан калуу (пропустить уроки), окуудан куулуу (быть отчисленнылм). Поскольку кыргызский язык образует слова при помощи аффиксации, появились производные слова: окумуштуу (ученый), окурман (читатель), окутуучу (учитель). Лексема «мектеп» (араб. بكتب - школа) - слово арабского происхождения, которое подразумевало мусульманскую начальную школу в странах Востока. В современном кыргызском языке данная лексема представляет начальную (башталгыч мектеп) и среднюю школу (орто мектеп). Также образована устойчивая фраза: жашоонун мектеби (икола жизни). Лексема «илим» также исконно тюркского происхождения, которая выражает совокупность фундаментальных и эмпирических знаний, т.е. науку. Данная лексема начала активно использоваться в XX веке и тем самым образовала научную терминологию в кыргызском языке: табият таануу илими (естественные науки), тил илими (языкознание), филология илимдеринин доктору (доктор филологических наук), медицина илимдеринин кандидать (кандидат медицинских наук), илимий стиль (научный стиль). Фразеологические единицы с данной лексемой весьма экспрессивны: илимдин туу чокусу (вершина науки), илимдин кени (клад знаний), илимге сугарылган (глубоко образованный, начитанный). Таким образом, концепт «билим» (знание) представляет большой интерес при изучении кыргызской языковой картины мира.

Кыргызская этнокультурная специфика в произведениях Ч. Айтматова занимает особое место, поскольку в них отражается целая картина мира кыргызского народа. Лингвокогнитивная точка зрения изучения его произведений открывает новые рубежи изучения 
концептов в произведениях писателя. Повесть «Биринчи мугалим» («Первый учитель») была издана в 1962 году в журнале «Ала-Тоо» под названием «Баллада о народном учителе». В 1963 году автор назвал его «Биринчи мугалим» («Первый учитель»). В повести Ч. Айтматов описывает эпохальную трансформацию кыргызского народа к пути образования и науки. Ч. Айтматов создал легенду об одном из таких людей - о первом учителе из аула Куркуроо Дюйшене Таштанбекове. В дореволюционном Кыргызстане школы назывались «медресе», а учителя — «молдо» до появления русско-туземных школ. Медресе (араб. مدرن - букв. «место, где изучают») как мусульманское учебное заведение обучало и грамотности, и основам ислама. Однако слова «мектеп» (школа) и «мугалим» (учитель) в начале XX века стали неологизмами в кыргызском языке, которые заменили «медресе» и «молдо». Лексемы «мектеп» (школа) и «мугалим» (учитель) уже имели «светское» значение. Лексема «мугалим» арабского происхождения стала частью активной лексики кыргызского языка. Имеется синоним к этому слову — исконно тюркская лексема «окутуучу», однако она имеет более книжную коннотацию. Само название «Биринчи мугалим» («Первый учитель») стало устойчивой фразой в кыргызском языке, тем самым оно имеет большое значение для каждого кыргыза, почитавшего своего первого учителя. В кыргызском языке обращение к учителю также выражается словами «агай» и «эжей», а также используется личное местоимение 3-го лица сиз. Как отмечает М.А. Атакулова, «в славянских и тюркских языках личные местоимения 1-го и 3-го лица содержат сем субъективной оценки по координатам «старший - младший», «уважаемый - неуважаемый», «выше посоциальному положению - ниже по социальному положению», «знакомый - незнакомый», «друг - недруг» и т.д. [4]. Таким образом, почтение к учителю в кыргызском языке выражается по иерархии «старший - младший».

С появлением данной повести в кыргызском языке образована метафора «Дүйшөндүн мектеби» - школа Дюйшена, которая означает «первую школу», иногда под этой метафорой подразумевается «ветхая школа», которая была построена очень давно. Концепт «билим» (зна- ние) в данном произведении вербализуется лексемами «окуу» (учеба), «Дүйшөндүн мектеби» (школа Дюйшена), «мугалим» (учитель), «мектеп директору» (директор школы), «жаңы мектеп» (новая школа) и др. Авторская концепция использования вышеуказанных лексем отражает жанровую принадлежность произведения. Концепт «билим» здесь выступает как художественный концепт. Как отмечают Е.В. Милейко и И.В. Рус-Брюшинина, «художественный концепт неразрывно связан с такими явлениями, как художественный текст, художественная картина мира, и потому рассматривается в комплексе лингвокультурных, лингвострановедческих, культурологических, психологических и других аспектов. Художественные произведения являются отражением как индивидуального сознания автора, так и всего этнокультурного сообщества, к которому он относится, что позволяет говорить как об авторской, так и о национальной концептосфере, отраженной в том или ином тексте» [8]. В этом произведении автор переосмыслил художественный символ знания в кыргызской картине мира. Знание становится знаком света и будущего кыргызского народа в XX веке. Например: Мектеп, окуy деген сөздөрдүн өздөрү эле биз үчүн анда анча тааныш эмес, жаны сөздөр [2]. - В те времена такие слова, как «школа», «учеба», были в новинку, и люди не очень-то в них разбирались [3]. Получение знаний в школе у народа вызывают удивление и недоумение: Мен молдо эмесмин, аксакал. Мен комсомолмун. Азыркы убакытта кат тааныгандарды мугалим дешет. Мен аскерде жүрүп кат таанып келдим. Менин молдолук жайым ошондой [2]. Я не мулла, аксакал, я комсомолеи, - быстро отозвался Дюйшен. - А детей теперь будут учить не мулль, а учителя. Я обучался грамоте в армии и до этого малость учился. Вот какой я мулла [3].

В языковой картине мира кыргызского народа не было понятия как «мугалим» (учитель), данная лексема заменяла слово «мулла», которая утратила свою функцию учителя. Открытие школы для народа было непонятным явлением: - Аныңдыкоё тур, окуунун бизге кереги эмне? Дүйшөн кандай дээрин билбей, көзу алацудай түштү. - Баса, тура айтат! - деп бер жактагылар да жабыла козголо берди. - Биз, жеркетмен деп, жерменен эле оокат кылган дыйканбыз. А биз- 
дин балдар окуу окуп, эл сурап, өкмөт болот беле? Кой, айланайын, башыбызды катырба? [2]. - Ты лучше скажи, зачем она нам, школа? - А верно ведь! — подхватил кто-то из толпы. И все разом зашевелились, зашумели. - Мы испокон веков живем дехканским трудом, нас кетмень кормит. И дети наши будут жить так же, на кой черт им учение? Грамота начальникам требуется, а мы простой народ. И не морочь нам голову! [3].

Несмотря на сопротивление народа, «первый учитель» отметил важность образования: Өкүмөт бизди эми көзү ачылсын, кат таанып, билимге жетилсин деп жатат. Мына, ошондуктан балдарды окутушубуз керек! [2]. - Мы жили в темноте. А теперь советская власть хочет, чтобы мы увидели свет, чтобы мы научились читать и писать. А для этого надо учить детей... [3].

Концепт «билим» (знание) относится к числу базовых концептов нынешнего кыргызского национального сознания. Однако, в начале XX века в менталитете кыргызского народа преобладало скептическое отношение к получению общеобразовательного образования. Ч. Айтматов уловил настроение народа того времени и использовал иронию для выражения негодования людей: Бу мектеп ачам деп кыйкырасыи, Үстүнудө тонун жок, астыңда атын жок, айдап койгон жериң жок, көздөп алган малың жок, сен эмне жылкы тийип оокат кыласыңбы? [2]. - Bот тыл на весь аил кричишь: «Школу буду открывать!» А поглядеть на тебя ни шуббл на тебе, ни коня под тобой, ни землищь вспаханной в поле, хоть бы с ладонь, ни единой скотинки во дворе! Так как же ть думаешь жить, дорогой человек? Разве что чужсие табуны угонять... Только у нас их нет. А у кого табуны есть - те в горах [3].

В авторской концепции знание ассоциируется с будущим народа: Анткени, ошондо биз үчүн, айыльнынын четине чыгыл көрбөгөн тоо койнундагы кыргыз балдары үчүн, бул мектеп деп аталган туш-туш жыртыгынан шамал вышкырып, эшигинин жылчыктарынан тээ алыстагы ак карлуу тоо чокулары көрүнгөн ыцшталган котур тамда кулак угуп, көз көрбөгөн укмуштуу жаңьы дүйнө ачылдыь [2]. - Да, это был подвиг, потому что в те дни нам, киргизским детям, нигде не бывавшим за пределами аила, в школе, если можно так назвать ту самую мазанку с зияющиим щчелями, через которые всегда были видны снежныле вершины гор, вдруг открылся новый, несльханный и невиданный прежде мир... [3]. Как полагает С. А. Аскольдов-Алексеев, в основе художественного концепта лежит образность. По его анализу, художественный концепт - это совокупность понятий, представлений, чувств, эмоций [1].

В анализируемом произведении чувствами и переживаниями героини Алтынай выражаются ее любовь к знаниям и ее почтение к учителю: Дүйшөн окуткан он чакты балдар-кыздардын ичинен чонураагы эле мен болчумун. Балкии, ошондуктан сабакть дурусураак билгени да мен элем. Бирок ал гана эмес, мугалимдин ар бир айткан сөзүн, көрсөткөн арип, жазууларын мен ьйылк түрдө көңүлүмө альп, бүт ьікласылм сальіп үйрөнө турганмылн. Мен Үчүн андан чоң, андан артык жумуш болгон эмес. Дүйшөндүн берген дептерин аяп, кай жерде жүрбөйүн, ороктун учу менен жерге чийип, дубал боорлоруна, кар үстүнө арып сальіп, сөз жазып окугам. Өз көңүлүмдө мен үчүн Дүйшөндөн жакшы, андан билимдүҮ киши болгон эмес [2]. - Среди учеников Дюйшена я была самой старшей. Возможно, поэтому я и училась лучше других, хотя, мне кажсется, не только поэтому. Каждое слово учителя, каждая буква, показанная им, - все для меня было свято. И не было для меня ничего важнее на свете, чем постигнуть то, чему учил Дюйшен. Я берегла тетрадь, которую он дал мне, и потому выводила буквы острием серпа на земле, писала углем на дувалах, прутиком на снегу ина дорожной пьли. Ине было для.меня на свете никого ученее и умнее Дюйшена [3].

Знание в авторской лингвокогнитивной репрезентации подчеркивает важность образования, особенно когда женщины и девочки, как Алтынай, сталкиваются с многочисленными трудностями, среди которых бедность и традиционные убеждения о статусе и роли женщин.

Несмотря на тот факт, что прошло много лет со дня опубликования повести «Биринчи мугалим» («Первый учитель») Ч. Айтматова, ее тематическая актуальность не утрачена. Авторская картина мира, выраженная концептом «билим» (знание) в повести «Биринчи мугалим» («Первый учитель») интерпретирует общечеловеческие ценности и национальное своеобразие. 


\section{Литература}

1. Аскольдов-Алексеев С.А. Концепт и слово // Русская словесность: от теории к структуре текста: антология / под ред. В.П. Нерознака. - М.: Academia, 1997. C. 267-279.

2. Айтматов Ч. Беш томдон турган чыгармалар жыйнагы. 1 том: Повесттер, аңгемелер. - Б.: Шам, 1999. — 432 с.

3. Айтматов Ч. Собрание сочинений в 7 томах. Составитель и редактор акад. Р. Рахманалиев. - Москва, 1998.

4. Атакулова М. Личные местоимения в языках различного строя: своеобразие и статус. Синергия. Научно-практический журнал. - 2018. - №3. - С. 34-39.

5. Галдин Е.В. Концепт «Вода» как полевая структура и способы его выражения в русском языке (На материале поэтических текстов И.А. Бродского): Дис. ... канд. филол. наук. - Пятигорск, 2006. - 175 с.

6. Древнетюркский словарь. - Л., 1969. - С. 369.

7. Жоламанова Е.И. Современные направления языкознания в Кыргызстане. Вестник КазНУ. Серия филологическая. 2011. — №3 (133). - С. 57-60.

8. Милейко Е.В., Рус-Брюшинина И. Художественный концепт как объект лингвистического исследования. Филологические науки. Вопросы теории и практики. - Тамбов: Грамота, 2016. - №11 (65): в 3-х ч. - Ч.3. C. $128-130$.

9. Погосян Р.Г. Концепт «Судьба» и его языковое выражение в поэтическом тексте Ф.К. Сологуба. Дис.. канд. филол. наук. Пятигорск, 2005.

\section{References}

1. Askol'dov-Alekseev S.A. Koncept i slovo [Concept and word] // Russkaja slovesnost': ot teorii k strukture teksta: antologija [Russian literature: from theory to text structure: an anthology] / In V.P. Neroznak (ed.). - Moscow: Academia, 1997. — Pp. 267-279.
2. Ajtmatov Ch. Besh tomdon turgan chygarmalar zhyjnagy. 1 tom: Povestter, aңgemeler. B.: Sham, 1999. - 432 p.

3. Ajtmatov Ch. Sobranie sochinenij v 7 tomah. Sostavitel' i redaktor akad. R. Rahmanaliev [Collected works in 7 volumes. The compiler and editor of Akad. R. Rakhmanaliev]. - Moscow, 1998.

4. Atakulova $M$. Lichnye mestoimenija v jazykah razlichnogo stroja: svoeobrazie i status. Sinergija. Nauchno-prakticheskij zhurnal [Personal pronouns in languages of different systems: originality and status. Synergy. Scientific and practical magazine]. — 2018. - №3. Pp. 34-39.

5. Galdin E. V. Koncept «Voda» kak polevaja struktura i sposoby ego vyrazhenija $v$ russkom jazyke ( $\mathrm{Na}$ materiale pojeticheskih tekstov I.A. Brodskogo): Dis. ... kand. filol. Nauk [The concept of «Water» as a field structure and ways of its expression in the Russian language (based on the material of I.A. Brodsky's poetic texts): Ph. D. (Philol.) Thesis]. — Pyatigorsk, 2006. $175 \mathrm{p}$.

6. Drevnetjurkskij slovar' [Ancient Turkic dictionary]. - Leningrad, 1969. - P. 369.

7. Zholamanova E.I. Sovremennye napravlenija jazykoznanija v Kyrgyzstane. Vestnik KazNU. Serija filologicheskaja [Modern directions of linguistics in Kyrgyzstan. Bulletin Of The Treasury. Philological series]. — 2011. №3 (133). - Pp. 57-60.

8. Milejko E.V., Rus-Brjushinina I. Hudozhestvennyj koncept kak ob'ekt lingvisticheskogo issledovanija. Filologicheskie nauki. Voprosy teorii i praktiki [Artistic concept as an object of linguistic research. Philological science. Questions of theory and practice]. - Tambov: Gramota, 2016. — №11 (65): in 3 parts. Part 3. - Pp. 128-130.

9. Pogosjan R. G. Koncept «Sud'ba» i ego jazykovoe vyrazhenie $\mathrm{v}$ pojeticheskom tekste F.K. Sologuba. Dis. kand. filol. nauk [The concept of «Fate» and its linguistic expression in the poetic text of F. K. Sologub. Ph. D. (Philol.) Thesis]. - Pyatigorsk, 2005. 


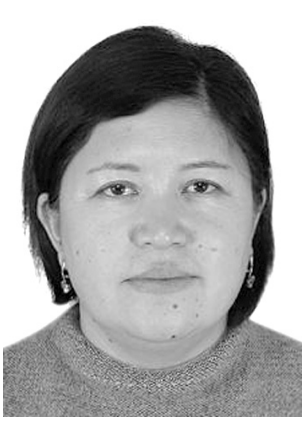

Абдурахманова Хулхарай Туланбаевна - старший преподаватель кафедры американистики и переводоведения Ошского государственного университета, г. Ош, Кыргызская Республика.

Abdurakhmanova Khulkharai Tulanbaevna - Senior Instructor, American Studies and Translation Department, Osh State University, Osh, Kyrgyz Republic.

723500, Кыргызстан, г. Ош, ул. Ленина, 331

331 Lenin st., 723500, Osh, Kyrgyzstan

E-mail: gulabdurahmanova81@gmail.ru 